\title{
Analysis of the behavior of a biomaterial based on wollastonite/TCP in the implant process of an experimental model of critical bone defects
}

\author{
Análise do comportamento de um biomaterial a base de wollastonita/TCP no processo de \\ implantação em modelo experimental de defeito ósseo crítico \\ Análisis del comportamiento de un biomaterial basado en wollastonita/TCP en el proceso de \\ implementación en un modelo experimental de defecto óseo crítico
}

Received: 06/04/2021 | Reviewed: 06/14/2021 | Accept: 06/18/2021 | Published: 07/02/2021

Mauricio Mitsuo Monção
ORCID: https://orcid.org/0000-0003-0183-1992
Federal Institute of Education, Science and Technology of Bahia, Brazil
E-mail: maurimitsuo@ yahoo.com.br
Raísa Cavalcante Dourado
ORCID: https://orcid.org/0000-0003-1446-0641
University of Bahia, Brazil
E-mail: raisadourado@ yahoo.com.br
Luisa Queiroz Vasconceos
University of Bahia, Brazil
ORCID: https://orcid.org/0000-0002-3916-8682
E-mail: luisa-queiroz@hotmail.com
Isabela Cerqueira Barreto
University of Bahia, Brazil
E-mail: isabelacbarreto@ hotmail.com
ORCID: https://orcid.org/0000-0003-2663-7395
Roberto Paulo Correia de Araújo
ORCID: https://orcid.org/0000-0001-7648-728X
University of Bahia, Brazil
E-mail: rpcaraujo@ hotmail.com

\begin{abstract}
This study analyzes the clinical, macroscopic and radiographic characteristics of a biomaterial with different proportions of wolastonite (W) and tricalcium phosphate (TCP) on bone tissue regeneration during the implantation process of an experimental model of critical bone defects. Fifteen Wistar rats were used, randomly distributed in 5 groups $(\mathrm{n}=3)$, with a bone defect created on an $8.0 \mathrm{~mm}$ diameter calvaria. 4 groups received implants with different proportions of $\mathrm{W} \% / \mathrm{TCP} \%$, referred to as $\mathrm{W} 20 / \mathrm{TCP} 80, \mathrm{~W} 40 / \mathrm{TCP} 60, \mathrm{~W} 60 / \mathrm{TCP} 40$ and $\mathrm{W} 80 / \mathrm{TCP} 20$. The fifth control group (GC) was filled with blood clot only. Clinical evaluation was performed every 24 hours, and after 7 days, the animals were euthanized. The calvaria were dissected and analyzed macroscopically and by radiography. All study groups showed a satisfactory clinical evolution. The macroscopic analysis showed filling of the bone defect with granules surrounded by newly formed tissue, and the radiographic analysis showed different patterns of displacement of the biomaterial. The study concluded that the different proportions of W\%/TCP\% were well tolerated by the study groups and demonstrated biocompatibility. The enhanced hydrophilic behavior of the W40/TCP60, W60/TCP40 and W80/TCP20 groups favored the application in the experimental model in vivo.
\end{abstract}

Keywords: Biomaterials; Bone regeneration; Calcium silicate; Calcium phosphates.

\section{Resumo}

O objetivo deste trabalho foi analisar características clínicas, macroscópicas e radiográficas de um biomaterial com diferentes proporções de wolastonita (W) e fosfato tricálcico (TCP) no processo de implantação em modelo experimental de defeito ósseo crítico, com finalidade de regeneração tecidual óssea. Foram utilizados 15 ratos Wistar, distribuídos aleatoriamente em 5 grupos $(\mathrm{n}=3)$, sendo confeccionado um defeito ósseo na calvária de $8,0 \mathrm{~mm}$ de diâmetro, onde 4 grupos receberam implantes com uma diferente proporção de W\%/TCP\%, denominados W20/TCP80, W40/TCP60, W60/TCP40 e W80/TCP20, e um grupo controle (GC) preenchido somente com coágulo sanguíneo. Realizou-se avaliação clínica a cada 24 horas, e após 7 dias, os animais foram eutanasiados, a calvária dissecada e analisada macroscopicamente e por radiografias. Todos os grupos do estudo apresentaram evolução clínica satisfatória. A análise macroscópica demostrou preenchimento do defeito ósseo com grânulos envoltos por tecido neoformado, e a análise radiográfica evidenciou diferentes padrões de deslocamento do biomaterial. Concluiuse que as diferentes proporções de W\%/TCP\% foram bem toleradas pelos grupos de estudo e demonstraram 
biocompatibilidade. O comportamento de maior hidrofilidade dos grupos W40/TCP60, W60/TCP40 e W80/TCP20 favoreceu a aplicação no modelo experimental in vivo.

Palavras-chave: Biomateriais; Regeneração óssea; Silicato de cálcio; Fosfatos de cálcio.

\section{Resumen}

El objetivo de este trabajo fue analizar el características clínicas, macroscópicas y radiográficas de un biomaterial con diferentes proporciones de wollastonita (W) y fosfato tricálcico (TCP) en el proceso de implantación en un modelo experimental de defecto óseo crítico, con el propósito de regenerar tejido óseo. Se utilizaron quince ratas Wistar, distribuidas aleatoriamente en 5 grupos $(\mathrm{n}=3)$, con un defecto óseo en la calvaría de $8.0 \mathrm{~mm}$ de diámetro, donde 4 grupos recibieron implantes con diferente proporción de W\%/TCP\%, denominados W20/TCP80, W40/TCP60, W60/TCP40 y W80/TCP20, y un grupo de control (GC) lleno solo de coágulo de sangre. La evaluación clínica se realizó cada 24 horas, y después de 7 días, los animales fueron sacrificados, la calvaría disecada y analizada macroscópicamente y por radiografía. Todos los grupos de estudio mostraron una evolución clínica satisfactoria. El análisis macroscópico mostró relleno del defecto óseo con gránulos rodeados de tejido neoformado y la análisis radiográfica mostró diferentes patrones de desplazamiento del biomaterial. Se concluyó que las diferentes proporciones de $\mathrm{W} \% / \mathrm{TCP} \%$ fueron bien toleradas por los grupos de estudio y demostraron biocompatibilidad. El mayor comportamiento de hidrofilicidad de los grupos W40/TCP60, W60/TCP40 y W80/TCP20 favoreció su aplicación en el modelo experimental in vivo.

Palabras clave: Biomateriales; Regeneración óssea; Silicato de calcio; Fosfatos de calcio.

\section{Introduction}

Tissue engineering seeks new technologies and biomaterials capable of treating extensive bone loss more efficiently when the possibility of spontaneous repair does not exist. From this perspective, there is current interest from researchers in the development of composite biomaterials, to develop physical-chemical properties that favor complex bone regeneration processes (Tanner, 2009; Santis, Guarino and Ambrosio, 2019).

Silicate glasses and calcium phosphate ceramics have been the focus of research seeking composite biomaterials that can fulfill the requirements for the structural and functional repair of bone tissue. Amongst such materials, wollastonite (W) has been widely studied as it presents biocompatibility, high mechanical resistance, and excellent bioactivity (Ke, et al., 2017). In addition, there is great interest in the tricalcium phosphate (TCP) phases which have crystallographic and chemical characteristics similar to the mineral phase of human bone tissue (Canillas, 2017; Grandi, 2011). These intrinsic properties have resulted in research developing composite biomaterial based on W and TCP with different proportions and can be associated with other biocompatible materials (Souza, 2020; Bagherifard, 2020).

It is understood that the development of materials intended to interact with biological systems to treat, augment or replace tissues, require adequate evaluation before application in humans. Experimental models utilizing an 8 mm diameter circular bone defect created in a rat calvaria are widely used in studies with biomaterials that evaluate bone repair (Schmitz, 1986). In these dimensions, the manufactured bone defect is referred to as critical, and allows analysis of the recipient's biological response to an implanted material without the interference of spontaneous bone repair (Takagui and Urist, 1982).

However, the evaluation of new biomaterials for bone regeneration can be compromised by numerous factors, which include the type of experimental model used during the in vivo test phase (Accorsi-Mendonça, et al., 2011). This study therefore analyzes the behavior of a biomaterials with differing proportions of W\%/TCP\% in the implantation process using critical bone defect model in rat calvaria. The study investigates the relevant clinical aspects, together with the physical requirements necessary for the safe application in the experimental model in vivo that favor bone tissue regeneration.

\section{Methodology}

\subsection{Biomaterial}

The experimental biomaterial used in the present study was created by mixing and sintering the minerals $\mathrm{W}$ and TCP, employing four different proportions of W\%/TCP\%, W20/TCP80, W80/TCP20, W40/TCP60 and W60/TCP40, into porous 
granules with sizes between $400 \sim 600 \mu \mathrm{m}$ and similar macroscopic aspects (Figure 1). The biomaterial was sterilized in a drying oven then fractionated in polypropylene tubes which had been previously labeled and sterilized by moist heat.

Figure 1: Macroscopic aspects of biomaterial W\%/TCP\%.

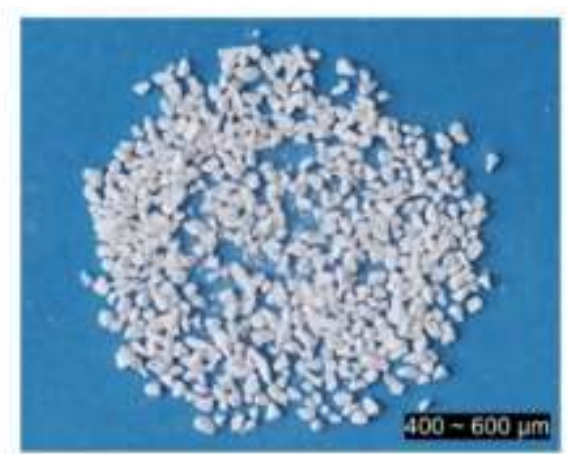

Source: Created by the authors (2021).

\subsection{Experimental groups}

The Ethics Committee on the Use of Animals at the University of Bahia, Bahia, Brazil, approved the experimental protocol No. 128/2017. The research applied the criteria for animal care developed by the National Academy of Sciences and described in the Guide for the Care and Use of Laboratory Animals (NRC, 2011), and followed the norms of the National Council for the Control of Animal Experimentation (CONCEA). Male albino rats (Rattus norvegicus) of the Wistar lineage with body mass between 350 and $400 \mathrm{~g}$ and age of approximately 4 to 5 months were used. The animals were kept in the vivarium in individual cages measuring $20 \times 30 \times 40 \mathrm{~cm}$, covered with an autoclaved pine shavings bed. They received food and water without restrictions and were acclimatized to a temperature of $22{ }^{\circ} \mathrm{C}( \pm 2)$, with alternating periods of light and darkness (12:12 hours). The animals were randomly distributed in 5 experimental groups of 3 animals each and underwent surgery to create a critical bone defect in a central portion of the calvaria. Four groups then received the biomaterial with one of the different proportions of W\%/TCP\%, called W20/TCP80, W40/TCP60, W60/TCP40 and W80/TCP20. Only 1 group, the control group (CG), did not receive implantation of biomaterial and the critical bone defect was filled by a blood clot.

\subsection{Pre-surgical}

The animals were sedated and anesthetized by an intraperitoneal injection of ketamine hydrochloride (Dopalen®) in the proportion of $7 \mathrm{mg} / 100 \mathrm{~g}$ of body mass, and xylazine hydrochloride (Anasedan ${ }^{\circledR}$ ) in the proportion of $0.8 \mathrm{mg} / 100 \mathrm{~g}$ of body mass. They were then placed in a prone position, the calvaria region was then shaved and submitted to antisepsis of the operative area with iodized alcohol.

\subsection{Surgical}

Aseptic techniques were rigorously observed throughout the procedure. The surgical technique employed in making the critical bone defect followed the protocol described by Spicer, et al. (2012). Surgical access was obtained in the median portion of the calvaria. A bicoronal cutaneous incision approximately $3 \mathrm{~cm}$ in length was made using the scalpel blade No. 15 and followed by the exposure and removal of the periosteum to expose the bone tissue. The elevation of the flap allowed access to the periosteum, which was removed with a spatula No. 7 (Duflex®) and clinical tweezers (Duflex®) to expose the bone tissue.

To create the critical bone defect, an $8.0 \mathrm{~mm}$ diameter trephine cutter (Dentoflex ${ }^{\circledR}$ ), was mounted on a contra angle (Driller $\left(\right.$ ) ) with a 16:1 reduction, coupled to an implant engine (Driller $\left.{ }^{\circledR}\right)$. The defect was drilled at $1500 \mathrm{rpm}$ under constant 
irrigation with saline solution. Following the creation of the defect, a circular fragment of bone tissue was removed from the upper portion of the calvaria exposing meningeal membranes and the underlying nervous tissue. The biomaterial was then implanted filling the entire area, followed by repositioning of the flap, and suturing with interrupted stitches in the cutaneous tissue. Aspects of the surgical process are shown in Figure 2.

Figure 2: Surgical process for creating and implanting the biomaterial in a critical bone defect.

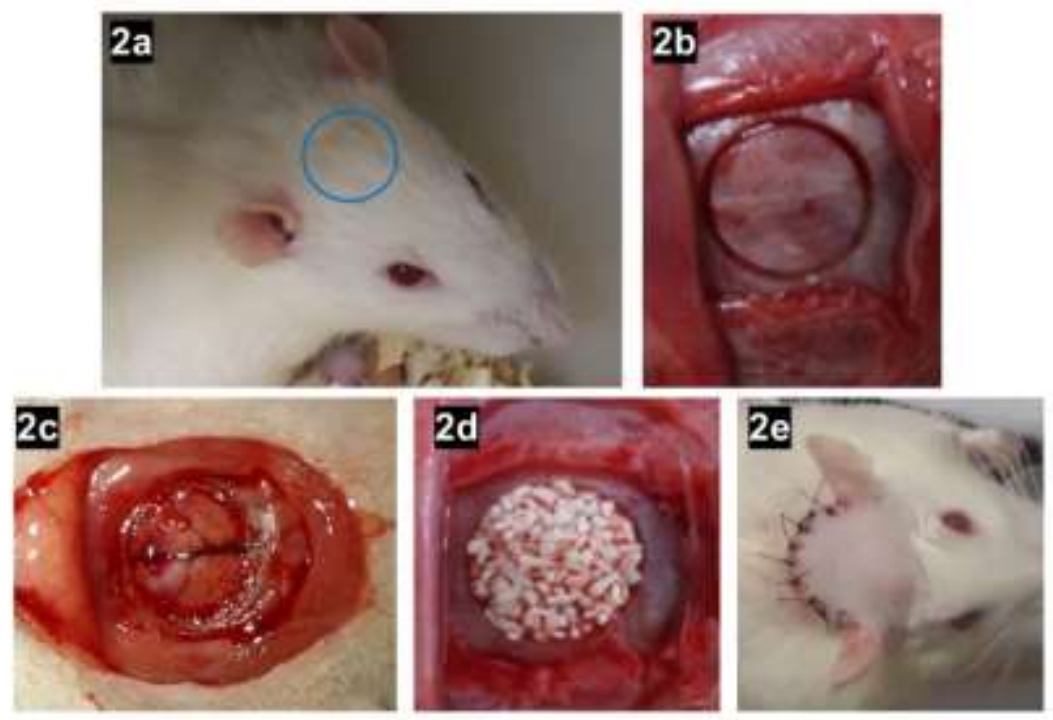

Note: (2a) Location of the median portion of the calvaria. (2b) Skin incision and exposure of the periosteum, its removal and exposure of bone tissue. (2c) Removal of the bone fragment visualization of the critical bone defect. (2d) Implementation of the granulated biomaterial. (2e) Suture in simple stitches.

Source: Created by the authors (2021).

Prior to implantation in the bone defect model, biomaterials were hydrated with $0.9 \%$ saline $(\mathrm{SF})$ at room temperature (Figure 3).

Figure 3: Aspects of the different proportions of W\%/TCP\% after hydration with SF $0.9 \%$.

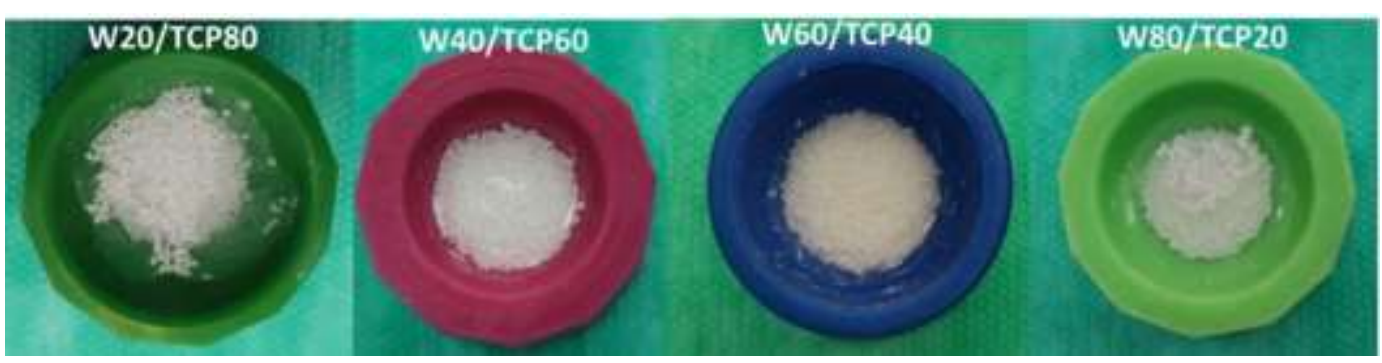

Source: Created by the authors (2021).

\subsection{Post-surgical}

After surgery, the animals were placed in individual boxes and monitored in a quiet, low-light environment with a controlled temperature between 27 and $30^{\circ} \mathrm{C}$ until complete recovery from anesthesia. They were then returned to the vivarium where they remained for seven days under the same conditions preceding the surgical process.

\subsection{Clinical evaluation of animals}

For seven days, corresponding to the post-surgical inflammatory phase, the animals were evaluated every 24 hours. The state of wakefulness, motor activity, temperament, posture, consumption of water and feed, excretion of urine and feces, 
were recorded together with the aspects of the surgical wound. Suppression of suffering and pain was predicted according to the Rat Grimace Scale (Sotocina, et al., 2011), which scores based on pain signals in rodents and indicates the need for analgesics for mild, moderate, and severe pain. Antibiotic prophylaxis was not performed, and the surgical wound was evaluated for inflammatory signs of erythema and edema together with the suture to identify possible infection.

\subsection{Euthanasia and collection of calvaria.}

When the seven day biological point was reached the animals were euthanized with intraperitoneal lethal injection of ketamine hydrochloride (Dopalen ${ }^{\circledR}$ ) in the proportion of $35 \mathrm{mg} / 100 \mathrm{~g}$ of body weight and xylazine hydrochloride (Anasedan ${ }^{\circledR}$ ) in the proportion of $4 \mathrm{mg} / 100 \mathrm{~g}$ of body weight. The rats were then dissected to expose the calvaria, disposing of all surrounding soft tissue except for the dura mater and periosteum. The specimens were fixed in $4 \%$ buffered formalin for 48 hours and reduced with carborundum disk No. 409 coupled to a mandrel and micro-grinding (Dremel®).

\subsection{Macroscopic and radiographic analysis}

The samples were subjected to macroscopic analysis with the aid of a 10x magnifying lens with polarized light (Lorben $\left({ }^{\circledR}\right)$. Two trained examiners inspected the explanted calvaria for texture and transparency of the soft tissues and evaluated possible abnormal infiltrates, thickening or defects of any type, as well as the presence or absence of the biomaterial that was implanted in the surgical bed. Subsequently these samples were $\mathrm{x}$-rayed using a digital CMOS sensor (Complementary Metal-Oxide Semiconductor) and optical fiber, external dimensions of $36.7 \mathrm{~mm}$ x $24.3 \mathrm{~mm}$ and theoretical resolution of $20 \mathrm{pl} / \mathrm{mm}$. Image receiver focus distance of $40 \mathrm{~cm}$ was used for and X-ray beam produced with $60 \mathrm{KVp}, 2 \mathrm{~mA}$ and 0.18 seconds of exposure.

\section{Results}

In general, the animals tolerated the surgical procedure well, became active and gradually returned to the diet of food and water without restriction. During the seven days of observation, there no animals died nor signs that indicated moderate or severe pain requiring analgesia. All animals in groups W40/TCP60 and W60/TCP40 showed similar aspects to animals in the CG during the waking state, being active in the presence of light and obtaining water and feed ad libitum, as well as similar evolution and no signs of exacerbation during the inflammatory phase.

Most animals in groups W20/TCP80 and W80/TCP20 followed a period similar to the CG, however, one animal in each group showed a waking state with less activity and smaller orbital opening when exposed to light in the first 48 hours after surgery. These animals showed increased signs of inflammation in the surgical wound, such as erythema and edema, without occurrence of dehiscence or discharge from the wound. At the end of the experimental period, these two animals showed delayed healing in relation to the other study groups.

The dissection of the calvaria verified that all the study groups showed formation of a transparent gelatinous tissue, involving the granules of the biomaterial. After complete dissection of the entire upper portion of the calvaria and removal of the soft tissues, filling of the created bone defect model with the biomaterial was observed (Figure 4). 
Figure 4: An example of calvaria demonstrates filling and tissue formation that involving granules of the biomaterial.

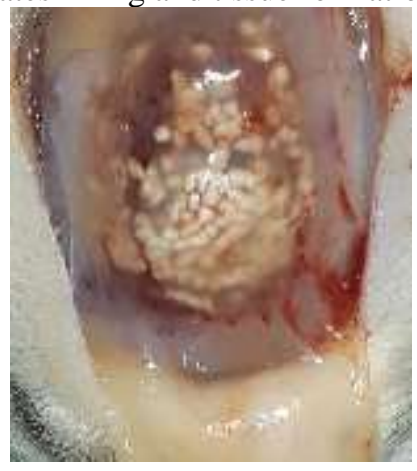

Note: all groups that received implants demonstrate similar filling and tissue formation that enveloped the biomaterial granules Source: Created by the authors (2021).

Aspects by group are shown in the calvaria specimens in Figure 5. The macroscopic analysis demonstrated granules of different sizes, arranged in mono, double or triple layer along the thickness of the defect, interspersed and surrounded by gelatinous and transparent newly formed tissue. The GC defect was filled only by a thin sheet of newly formed tissue with a thickness less than that of the remaining bone and firmly adhered to the edges of the defect. In the groups that received implants different amounts of granules from the biomaterial were observed outside the borders of the bone defect, and considerably more for the W20/TCP80 group.

Figure 5: Macroscopic aspects of the calvaria specimens of the groups under study.
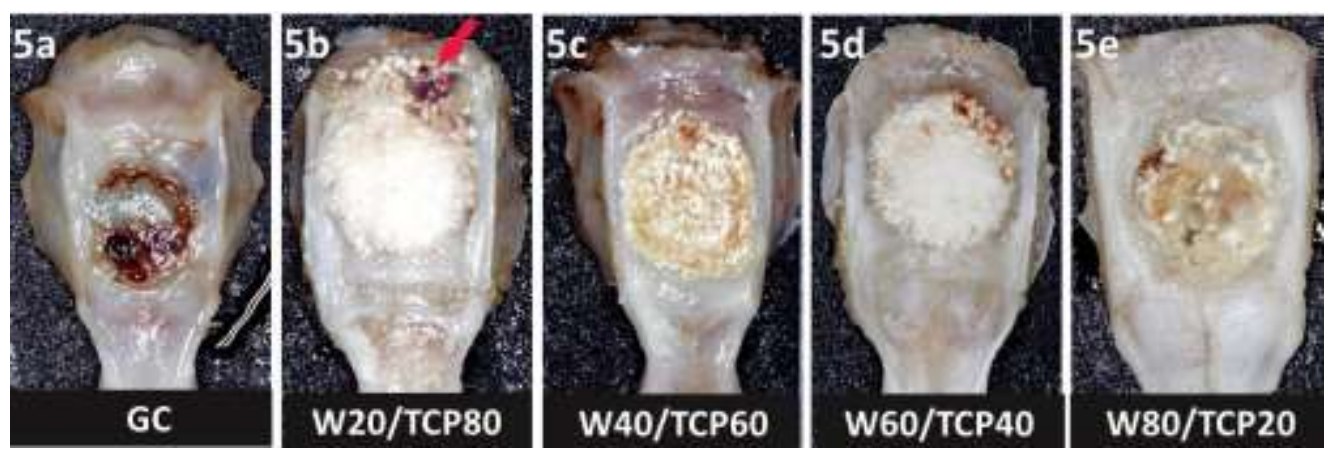

Note: (5a) GC with bone defect filled only by a tissue slide. (5b) Greater displacement of the granules observed (arrow) in the W20/TCP80 group. (5c and 5d) Biomaterial granules interspersed and surrounded by gelatinous substance filling all bone defects. (5e) The W80/TCP20 group exhibiting reduction of granules, compatible with the higher proportion of W.

Source: Created by the authors (2021).

In the radiographic analysis the images demonstrate the permanence of the critical bone defect in the CG with precise limits and the absence of the characteristic radiographic density of the bone tissue. In groups with implants the images show granules with a density greater than the adjacent bone and different patterns of displacement out of the bone defect. In groups W40/TCP60, W60/TCP40 and W80/TCP20 it is possible to confirm less displacement of the granules and adequate filling of the bone defect evidenced by the overlapping of the radiographic density of the granules at the implant site. However, for the W20/TCP80 group, the radiographs showed considerable displacement of the granules from the biomaterial, evidenced by the radiographic density of the granules outside the area of the bone defect, with the presence of hypodensity corresponding to the failure of filling the model with the biomaterial (Figure 6). 
Figure 6: Representative radiographic images for the study groups.
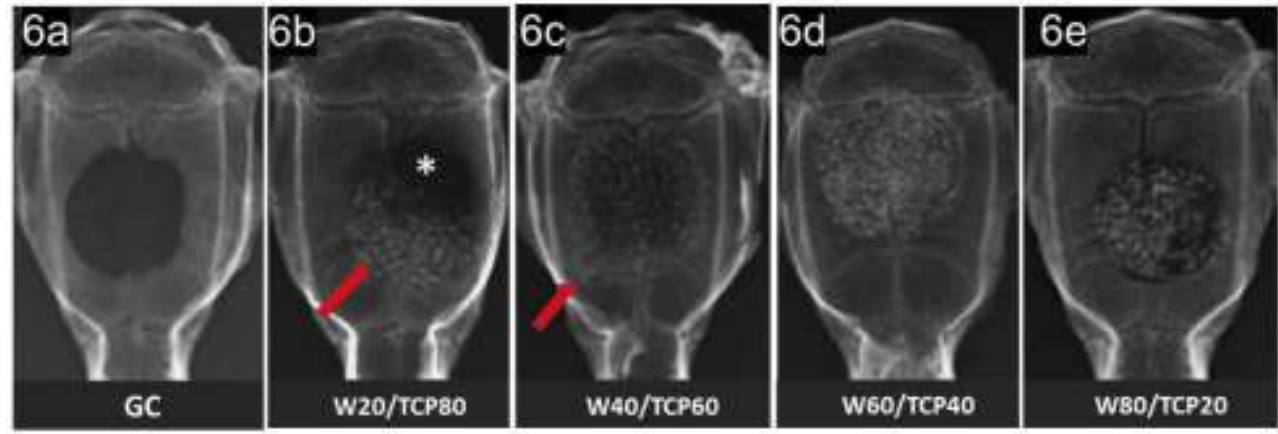

Note: (6a) Aspects of the critical bone defect in the calvaria of the CG. (6b) For the W20/TCP80 group, the arrow indicates undesirable displacement of the biomaterial, which resulted in filling failure (asterisk). (6c) In the W40/TCP60 group, there was displacement of the granules (arrow), however, with the bone defect being filled in a desirable way with the biomaterial. (6d) Group W60/TCP40 exhibited less displacement of the granules and excellent filling. (6e) Group W80/TCP20 with desirable filling of the bone defect. It is possible to observe reduction of the granules.

Source: Created by the authors (2021).

\section{Discussion}

The experimental groups in the present study tolerated the surgical procedure well, together with the implantation of different percentage compositions of W\%/TCP\% of the biomaterial. The analysis of a biomaterial based on TCP by Souza, et al. (2020), reinforced with $10 \% \mathrm{~W}$, performed in a rat calvaria bone defect model, concluded that the biomaterial was shown to be biocompatible, non-cytotoxic, resorbable and capable of inducing new bone formation. In this study, the inflammatory phase occurred in a similar way for most animals in the study groups, with the lack of inflammatory signals demonstrating biocompatibility. In addition, no signs of infection were observed during the analysis period which can be attributed to maintaining the aseptic chain during the surgical process and adequate sterilization of the biomaterial by dry heat.

Barbosa, et al. (2019), in a study with rabbits, evaluated implants in of bone model defects in tibias, which received scaffolds developed with a composition of $40 \%$ TCP and $60 \% \mathrm{~W}$. This study concluded that the animals did not show clinical signs of implant rejection and went through the post period -surgical without signs of toxicity of the biomaterial. In this study with rats, the experimental groups showed similar clinical results, no moderate or severe pain, no signs of exaggerated inflammatory response or infection, and it is possible to state that the different proportions show good biocompatibility and biological safety.

According to Spicer, et al., (2013), the experimental model using a rat calvaria critical bone defect presents major obstacle to spontaneous bone regeneration due to its morphology, and a reduced source of osteoprogenitor cells. and Gomes and Fernandes (2011) the experimental model using a rat calvaria critical bone defect presents major obstacle to spontaneous bone regeneration due to its morphology, and a reduced source of osteoprogenitor cells. In this sense, the characteristics of the biomaterial studied such as the size and shape of the granules, allowed the complete filling of the bone defect model, providing a means for cell migration.

The retention and disposition of the biomaterial in the implanted location is influenced by the properties of its micro and macrostructure. Therefore, the size, shape and surface area of the granules determine the surface energy, cellular interactivity, and repulsion force between the particles (Zhao, et al., 2007). In this study, it was observed that the size and shape of the granules of the biomaterial provided adequate arrangement and permanence in the intergranular space. Such characteristics favor the diffusion of nutrients and growth factors which together with angiogenesis are essential to the cellular activities observed during tissue repair (Bouler, 2017). 
Regarding surface energy, when hydrated with $0.9 \% \mathrm{SF}$ at room temperature, the granules of the proportions W40/TCP60, W60/TCP40 and W80/TCP20 showed greater hydrophilicity however the proportion W20/TCP80 is less hydrophilic. It is known that the free surface energy determines whether a biomaterial is hydrophilic or hydrophobic, directly influencing its wettability. Research such as the study by Nakamura, et al. (2015), demonstrates the importance of the wettability of ceramic-type biomaterials, in which the authors used polarization treatment to increase the electrical charges on the surface of biomaterials including hydroxyapatite, calcium and beta tricalcium phosphate. It was found that the increase in free electrical charges on the surfaces resulted in better surface wettability performance related to better performance for osteoconductivity. Other studies (Khaskhoussi, et al., 2019; Pires, 2020) have evaluated ceramic composites and concluded that wettability is relates to the high osteointegration capacity of these materials.

In the present study the compositions implanted in the groups W40/TCP60, W60/TCP40 and W80/TCP20 showed greater hydrophilicity behavior. The compositions formed aggregates that allowed easier handling, implantation, and greater permanence of the biomaterial granules in the receiving bed resulting in complete filling of the critical bone defect model. The composition implanted in the W20/TCP80 group showed little hydrophilic behavior with the granules remaining dispersed in the liquid which hindered its handling and implantation in the model. This resulted in a greater displacement of the biomaterial out of the bone defect and causing failure of filling of the recipient bed.

In the application of a critical bone model defect in rat calvaria these findings are relevant. The granules of the biomaterial based on $\mathrm{W} \% / \mathrm{TCP} \%$ must fill the model uniformly, such that the mineral phase $\mathrm{W}$ provides structural reinforcement and bioactive ions through their dissolution in biological fluids. The TCP mineral phase, which has biodegradation and slower resorption rates, serves as a framework favoring osteoconductivity (Almeida, et al., 2020; Palakurthy and Samudrala, 2019).

\section{Conclusion}

Clinical, macroscopic and radiographic characteristics confirmed that all study groups tolerated the implantation of the biomaterial well and the different proportions of $\mathrm{W} \% / \mathrm{TCP} \%$ demonstrated biocompatibility. The physical requirements in the shape and size of the granules enabled to satisfactory filling of the bone defect all groups however the less hydrophilic behavior of the W20/TCP80 group resulted in greater difficulty in handling and greater displacement of the granules after implantation. The increased hydrophilic behavior of the W40/TCP60, W60/TCP40 and W80/TCP20 groups favored the application in the experimental model in vivo.

\section{Acknowledgments}

The authors would like to thank the Research Support Foundation of the State of Bahia - FAPESB, the Institute for Ceramics and Glass in Madrid Spain. The Materials Characterization Laboratory, The Radiological Physics Laboratory, and the Department Health Technology and Biology - DTSBio of the Federal Institute of Education, Science and Technology of Bahia - IFBA. Special thanks also to Professor Fabiana Pain Rosa.

\section{References}

Tanner, K. E. (2017). Hard tissue applications of biocomposites. Editor: Luigi Ambrosio, In Woodhead Publishing Series in Biomaterials, Biomedical Composites (Second Edition), 37-58.

De Santis, R., Guarino, V., \& Ambrosio, L. Composite biomaterials for bone repair. Editor(s): Kendell M. P., Josep A. P., In Woodhead Publishing Series in Biomaterials, Bone Repair Biomaterials (Second Edition), Woodhead Publishing, 2019, Pages 273-299. 
Ke, X., Zhuang, Z., Yang, X., Fu, J., Xu, S., Xie, L., Gou, Z., \& Yang, G. (2017). Enhancing the Osteogenic Capability of Core-Shell Bilayered Bioceramic Microspheres with Adjustable Biodegradation. ACS Applied Materials \& Interfaces, 2017:9(29).

Canillas, M., Pena, P., De Aza, A. H., \& Rodríguez, M. A. (2017). Calcium phosphates for biomedical applications. Boletín de la Sociedad Española de Cerámica y Vidrio, 56, 91-112.

Grandi, G., Heitz, C., Dos Santos, L. A., Silva, M. L., Sant'Ana Filho, M., Pagnocelli, R. M., \& Silva, D. N. (2011). Comparative histomorphometric analysis between $\alpha$-Tcp cement and $\beta$-Tcp/Ha granules in the bone repair of rat calvaria. Materials Research, 14, 11-16.

De Souza, A. C., McNulty, C., Camilli, J. Â., Bertran, C. A., \& De Souza, M. M. Calcium Phosphate Cement Plus $10 \%$ Wollastonite Whiskers: An In Vivo Study. Journal of Biomimetics, Biomaterials and Biomedical Engineering, 47, 117-126.

Bagherifard, A., Yekta, H. J., Aghdam, H. A., Motififard, M., Sanatizadeh, E., Nejad, M. G., Esmaeili, S., \& Khandan, A. (2020). Improvement in osseointegration of tricalcium phosphate-zircon for orthopedic applications: an in vitro and in vivo evaluation. Medical \& Biological Engineering \& Computing, 58, 1681-1693.

Schmitz, J. P., Schwartz Z., Hollinger, J. O., \& Boyan, B. D. (1980). Characterization of rat calvarial nonunion defects. Acta Anatomica, 138:185-192.

Takagi, K., \& Urist, M. R. (1982). The reaction of the dura to bone morphogenetic protein (BMP) in repair of skull defects. Annals of Surgery. 196, 100-109.

Accorsi-Mendonça, T., Zambuzzi, W. F., Bramante, C. M., Cestari, T. M., Taga, R., Sader, M., de Almeida Soares, G. D., \& Granjeiro, J.M. (2011). Biological monitoring of a xenomaterial for grafting: an evaluation in critical size calvarial defects. The Journal of Materials Science, $22,997-1004,2011$.

National Academy of Sciences. (2011). Guide for the care and use of laboratory animals. Eighth edition. Committee for the update of the guide for the care and use of laboratory animals. Institute for laboratory animal research. 2011.

Spicer, P. P., Kretlow, J. D., Young, S., Jansen, J. H., Kasper, F., K., \& Mikos, A. G. (2012). Evaluation of bone regeneration using the rat critical size calvarial defect. Nature Protocol, 7, 1918-1929.

Sotocina, S. G., Sorge, R. E., Zaloum, A., Tuttle, A. H., Martin, L. J., Wieskopf, J. S., Mapplebeck, J. C. S., \& Zhang, S. (2011). The Rat Grimace Scale: a partially automated method for quantifying pain in the laboratory rat via facial expressions. Molecular Pain, 7, 1744-8069.

Barbosa, W. T., de Almeida, K. V., de Lima, G. G., Rodriguez, M. A., Lia Fook, M. V., García-Carrodeguas, R., Silva Junior, V. A., \& de Sá, M. J. C. (2019). Synthesis and in vivo evaluation of a scaffold containing wollastonite/ $\beta$-TCP for bone repair in a rabbit tibial defect model. Journal of Biomedical Materials Research Part B: Applied Biomaterials, 108(3): 1107-1116, 202004.

Bouler, J. M., Pilet, P., Gauthier, O., \& Verron, E. (2017). Biphasic calcium phosphate ceramics for bone reconstruction: A review of biological response. Acta Biomaterialia, 53, 1-12

Nakamura, M., Hori, N., Namba, S., Toyama, T., Nishimiya, N., \& Yamashita, k. (2015). Wettability and surface free energy of polarised ceramic biomaterials. Biomedical materials, 10(1):011001.

Khaskhoussi, A., Calabrese, L., Currò, M., Ientile, R., Bouaziz, J., \& Proverbio, E. (2020). Effect of the Compositions on the Biocompatibility of New Alumina-Zirconia-Titania Dental Ceramic Composites. Materials, 13(6):1374.

Almeida, R. S., Prado da Silva, M. H., Navarro da Rocha, D., Ribeiro, I. I. A., Barbosa Júnior, A. A., Miguel, F. B., \& Rosa, F. P. (2020). Regeneração de defeito ósseo crítico após implantação de fosfato de cálcio bifásico ( $\beta$-fosfato

de Oliveira, R. C. \& Borges, A. F. S. B. (2020). Wettability and pre-osteoblastic behavior evaluations of a dense bovine hydroxyapatite tricálcico/pirofosfato de cálcio) e vidro bioativo fosfatado. Cerâmica, 66, 119-125.

Palakurthy, S., Reddy, V. G. K., Samudrala, R. K., \& Azeem, A. P. (2019). In vitro bioactivity and degradation behaviour of $\beta$-wollastonite derived from natural waste. Materials Science and Engineering C: Materials for Biological Applications, 98:109-117.

Pires, L. A., de Meira, C. R., Tokuhara, C. K., de Oliveira, F. A., Dainezi, V. B., Zardin, M. S. G., Fortulan, C. A., ceramics. Journal of Oral Science. 62. 259264. 